\title{
Hepatitis B virus DNA-induced carcinogenesis of human normal liver cells by virtue of nonmethylated CpG DNA
}

\author{
XUDONG LIU, QIHUAN XU, WEI CHEN, HONG CAO, RONGJIONG ZHENG and GANG LI \\ Department of Infectious Disease, the Third Affiliated Hospital of Sun Yat-sen University, \\ 600 Tianhe Road, Guangzhou 510630, P.R. China
}

Received December 9, 2008; Accepted February 7, 2009

DOI: $10.3892 /$ or_00000307

\begin{abstract}
Hepatitis B virus has been linked to the pathogenesis and carcinogenesis of hepatocellular carcinoma. Components of viruses have been identified within pathological specimens of hepatocellular carcinoma tissue. We characterized the in vitro response of human normal liver cells (L-02 cells) to components of infectious agents related to toll-like receptors. Immortalized human normal liver cells (L-02 cells) exhibited increased proliferation in response to exposure to CpG DNA. This molecule is a well-characterized surrogate for DNA viruses, which are common in the liver. Our experiments show that L-02 cells and some hepatoma cell lines such as HepG2, HuH7, Hep3B, express TLR 9 (CpGspecific). CpG DNA, HBV DNA, DNA of HBV middle envelope protein (MP) containing a number of $\mathrm{CpG}$, supernatant of HepG2.2.15 (HepG2 cells transfected HBV) excreting HBV DNA and extraction of nucleic acids from HepG2.2.15 supernatant can all activate NF-кB. In addition, L-02 cells were less susceptible to TNF- $\alpha$-induced apoptosis as measured by Annexin V-FITC staining when stimulated with CpG. mRNA of DNA methyltransferase 1 (DNMT-1) and BCL-2 was increased when L-02 cells were stimulated with CpG DNA. Our study has identified a possible novel mechanism that indicates how CpG DNA of HBV DNA may contribute to the malignant transformation of benign liver cells.
\end{abstract}

\section{Introduction}

HCC is the main cause of death in cirrhotic patients and has become a major health problem in many countries. As well, HCC is one of the most common malignancies worldwide, with an estimated annual incidence of 1 million cases (1). While development of the disease is multi-factorial including $\mathrm{HBV}$, hepatitis $\mathrm{C}$ virus (HCV), aflatoxin, alcohol consumption

Correspondence to: Dr Gang Li, Department of Infectious Disease, the Third Affiliated Hospital of Sun Yat-sen University, 600 Tianhe Road, Guangzhou 510630, P.R. China

E-mail: liganglxd@126.com

Key words: hepatitis B virus, $\mathrm{CpG}$, carcinogenesis, L-02 cells, $\mathrm{NF}-\kappa \mathrm{B}$ and hemochromatosis (2). The toll-like receptors (TLRs) represent a primary defense against pathogens in the innate immune response (3). More than 10 mammalian Toll receptors have been identified and are involved in the recognition of microbial patterns (4). Each TLR recognizes a different, highly conserved structural motif found on many pathogens that results in the activation of transcription factors such as $\mathrm{NF}-\kappa \mathrm{B} . \mathrm{NF}-\kappa \mathrm{B}$ activation is a very important reason for cell cancerization. CpG DNA is the ligand of TLR9. HBV DNA is rich in $\mathrm{CpG}$. If these agents can activate NF-кB is unknown. We hypothesized that exposure of normal liver cells to components of viral pathogens might alter the character and proliferation. To test this hypothesis we used an in vitro approach employing cultured human normal liver L-02 cells treated with CpG DNA, HBV DNA, etc. We demonstrate that exposure to $\mathrm{CpG}$ DNA may contribute to hepatoma carcinogenesis.

\section{Materials and methods}

Cell culture and reagents. L-02 cells, HepG2, HuH7, Hep3B, HepG2.2.15 (excreting HBV DNA and transfected full-long HBV DNA) cells were cultured in Dulbecco's modified Eagle's medium (DMEM, Invitrogen Corporation, Carlsbad, USA) supplemented with $10 \%$ heat-inactivated fetal bovine serum (FBS) (Hyclone Corporation, Logan, USA) and 1:100 penicillin/streptomycin at $37^{\circ} \mathrm{C}$ in $5 \% \mathrm{CO}_{2}$ atmosphere. HepG2.2.15 cells were supplemented with G418 (200 $\mu \mathrm{g} /$ $\mathrm{ml}$ ). TNF- $\alpha$ was from PeproTech Inc (cat NO. 300-01A, Rocky Hill, NJ, USA). TLR9 (cat NO. 14-9099) was from eBioscience, Inc (San Diego, CA, USA).

Immunocytochemistry stain for TLR9. For the immunocytochemistry staining, the cells were planted on glass coverslips in normal culture medium. The cells were fixed with $4 \%$ paraformaldehyde-phosphate-buffered solution (PBS) for $20 \mathrm{~min}$ at $4^{\circ} \mathrm{C}$, after which they were permeabilized with $0.5 \%$ Triton-100 for $10 \mathrm{~min}$. Then blocking for $30 \mathrm{~min}$ the samples with $10 \%$ bovine serum album (BSA), staining with mouse monoclonal antibody to TLR9 was performed by applying the diluted antibody 1:100 in Tris-buffered saline (TBS) to the coverslips. Horseradish peroxidase (HRP)conjugated anti-mouse antibody diluted 1:500 in TBS was used to visualize the staining. At last, hematoxylin was used to stain cell nucleus. The samples were then examined using a light microscope. 
Cell proliferation assay. Cell viability was evaluated via 3[4,5-dimethylthiazol-2-yl]-2, 5-diphenyl tetrazolium bromide (MTT) reduction assay. Three thousand cells per well were plated in a 96-well plate and subjected to $\mathrm{CpG}$ DNA in increasing concentrations. Six parallel wells were set. The sequence of the non-methylated CpG DNA was 5'-TCGTCG TCGTTCGAACGACGTTGAT-3' the control sequence is non-CpG DNA, 5'-TGCTGCTGCTTGCAAGCAGCTT GAT-3' (synthesized by Sbsbio Corporation, Beijing, China). Cells were treated for $24 \mathrm{~h}$, after which supernatant was removed and $10 \%$ MTT serum-free medium $100 \mu \mathrm{l}$ was added to each well and incubated at $37^{\circ} \mathrm{C}$ in $5 \% \mathrm{CO}_{2}$ atmosphere. For an additional $4 \mathrm{~h}$, supernatant was removed carefully and $100 \mu \mathrm{l}$ fetal dimethyl sulfoxide (DMSO) was added in each well. After shake slightly for $10 \mathrm{~min}$, absorbance was read with filter in the wavelength $570 / 630 \mathrm{~nm}$. Determine the average values from triplicate readings and subtract the average value for the blank. AVONE was performed to analyze statistical significance.

Reverse transcriptase PCR for TLR9 and real-time reverse transcriptase PCR for DNMT-1 and Bcl-2. RNA was harvested using a RNA isolation kit (Tiangen, Beijing, China) acting on the manual. RT PCR was performed using the SuperScript III Cells Direct cDNA Synthesis kit [Taraka Biotechnology (Dalian) Co., Ltd., Dalian, China]. TLR9 primers were as follows: upstream primer 5'-CATGCCCTGCGCTTCCTA TTC-3', downstream primer 5'-AGCTTGCGCAGCTGTG TTAGG-3'. The expected amplification size was $518 \mathrm{bp}$. Amplification size was compared to a 600 bp Plus DNA ladder (Tiangen Corporation). PCR was performed at $94^{\circ} \mathrm{C}$ $30 \mathrm{sec}, 58^{\circ} \mathrm{C} 30 \mathrm{sec}$ and $72^{\circ} \mathrm{C} 40 \mathrm{sec}$ for 30 cycles. PCR products were separated on a $2 \%$ agarose gel and analyzed using a Gel Doc 2000 system (Bio-Rad, Hercules, CA). DNMT-1 primers were as follows: upstream primer 5'AGGGAAAAGGGAAGGGCAAG-3', downstream primer 5'-AGAAAACATCCAGGGTCCG-3'. Bcl-2 primers were as follows: upstream primer 5'-CATGTGTGTGGAGAGCGT CAA-3', downstream primer 5'-GCCGGTTCAGGTACT CAGTCA-3'. GAPDH primers were as follows: upstream primer 5'-GCACCGTCAAGGCTGAGAAC-3', downstream primer 5'-TGGTGAAGACGCCAGTGGA-3'. Real-time PCR were performed using the SYBR-Green DNA Amplification Kit (Taraka Biotechnology) on the ABI Prism 7300HT sequence detection system (Applied Biosystems, Foster City, USA). Quantitation was accomplished by measuring the incorporation of the fluorescent dye SYBRGreen-II into the PCR product. PCR was programmed for $95^{\circ} \mathrm{C}$ for $10 \mathrm{sec}$, then 40 cycles of $95^{\circ} \mathrm{C}$ for $5 \mathrm{sec}, 60^{\circ} \mathrm{C}$ for $31 \mathrm{sec}$. The amplification results were analyzed using SDS 2.2.1 software (Applied Biosystems) and the genes of interest were normalized to the corresponding GAPDH results. Data were expressed as fold induction relative to the control. All PCR were performed in triplicate. Paried t-test was performed to analyze statistical significance.

$N F-\kappa B$ activation measure. NF-кB activity was measured by using NF- $\mathrm{B}$ Activation-Nuclear Translocation Assay kit (Beyotime, Suzhou, China). NF-кB activation is to be confirmed via immunofluorescence staining to NF- $\mathrm{KB}$ p65 subunit in cell nucleus, whereas NF- $\mathrm{BB}$ expresses in cytoplasm before activated. Cells $\left(5 \times 10^{5}\right)$ were planted on glass coverslips in 6-well plate in normal medium. After $24 \mathrm{~h}$ supernatant was removed and serum-free medium was added $\mathrm{CpG}$ $(1 \mu \mathrm{M})$ or non-CpG $(1 \mu \mathrm{M})$ or HBV DNA $(4 \mu \mathrm{g} / \mathrm{ml})$ or DNA of HBV envelope middle protein $(2 \mu \mathrm{g} / \mathrm{ml})$ or DNA of $\mathrm{S}$ envelope protein (SP) $(2 \mu \mathrm{g} / \mathrm{ml})$ for $4 \mathrm{~h}$. In addition, supernatant of HepG2.2.15 cells or HepG2 cells $\left(5 \times 10^{5}\right.$ cells were cultured for a day) were in the place of medium, then used to stimulate human normal liver L-02 cells for $4 \mathrm{~h}$. HepG2.2.15 supernatant and HepG2 supernatant $\left(5 \times 10^{6}\right.$ cells were cultured for $48 \mathrm{~h}$ ) were used to extract nucleic acids with Phenyl hydrate/chloroform and ethanol precipitation. Extraction of nucleic acids from HepG2.2.15 supernatant and HepG2 supernatant was added in $1 \mathrm{ml}$ serum-free medium of L-02 cells for $4 \mathrm{~h}$. Diamidino-phenyl-indole (DAPI) staining was used to locate the nucleus. The number of positive cells magnified x200 for NF-кB nuclear translocation staining and 16 fields were counted. AVONE was performed to analyze statistical significance.

Cellular apoptosis analysis. Apoptosis was analyzed by fluorescence activated cell sorter (FACS) employing Annexin V-fluorescein isothiocyanate (FITC) apoptosis detection kit (Keygen Biotech. Co. Ltd. Nanjing, China) L-02 cells $\left(5 \times 10^{5} / \mathrm{ml}\right)$ were treated with TNF- $\alpha(100 \mathrm{ng} / \mathrm{ml})$ for $24 \mathrm{~h}$ in the absence of $\mathrm{CpG}(1 \mu \mathrm{M})$ or non-CpG $(1 \mu \mathrm{M})$. Then, the cells were harvested and washed in PBS, resuspended in pre-diluted binding buffer and stained with Annexin V-FITC for $20 \mathrm{~min}$ at room temperature, protected from light. Then cells were washed and resuspended in propidium iodide (PI) binding buffer, and apoptosis of cells analyzed immediately by flow cytometry using CellQuest Software.

Statistical analyses. Data are presented as mean \pm standard deviation (SD). Statistical analysis was performed using AVONE or paried t-test analyses using SPSS11.5 soft-ware. $\mathrm{P}<0.05$ was considered to be statistically significant.

\section{Results}

TLR9 are present on L-02 cells and HepG2, HuH7, Hep3B cells. RT-PCR confirmed the presence of TLR9 (Fig. 1A). TLR9 (Fig. 1B) were expressed on L-02 cells as demonstrated by immunocytochemistry staining contrasting to negative control (Fig. 1C). HepG2, HuH7, Hep3B cells all express TLR9 at the lever of mRNA and protein (data not shown).

CpG DNA stimulate proliferation of human normal liver L-02 cells. We determined whether CpG DNA could influence live cell line L-02 cell proliferation as measured by MTT reduction assay. Different doses of CpG DNA $(0.1,1,5$ and $10 \mu \mathrm{M})$ or non-CpG DNA $(0.1,1,5$ and $10 \mu \mathrm{M})$ were used to stimulate L-02 for $24 \mathrm{~h}$. CpG DNA caused an increase in cell prolifer-ation at all doses from 0.1 to $10 \mu \mathrm{M}$, maximum level was seen at the dose $1 \mu \mathrm{M}$ (Fig. 2A). Non-CpG DNA did not stimulate the proliferation of L-02 cells (Fig. 2B). These results show that both human normal liver L-02 cells 

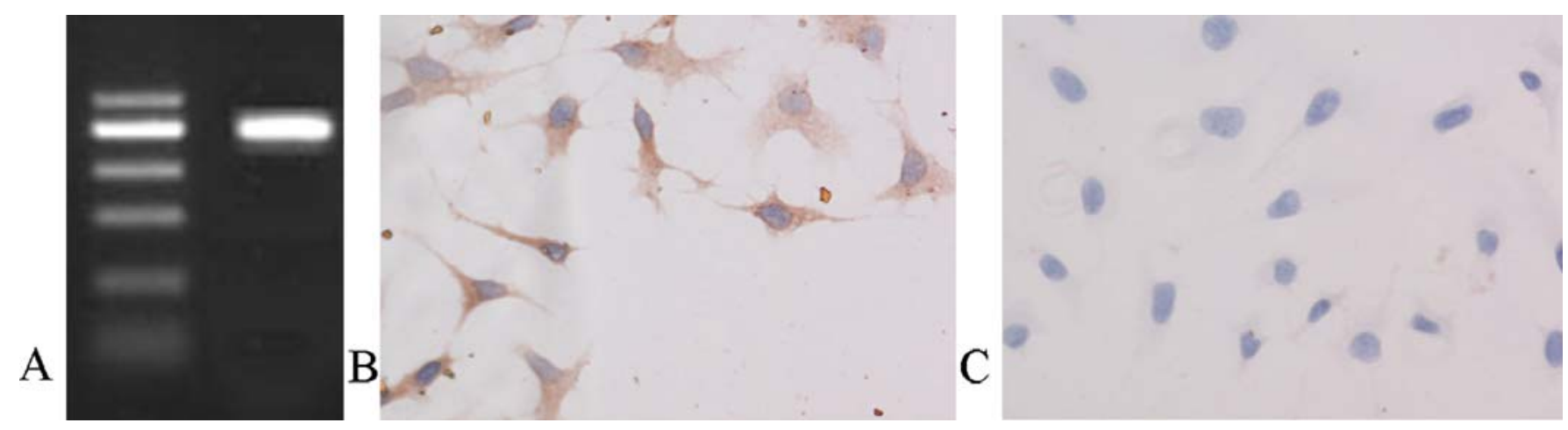

Figure 1. TLR9 is expressed in human normal liver L-02 cells. TLR9 (A) is present on L-02 cells as demonstrated by RT-PCR. TLR9 is present in L-02 cells as demonstrated by immunocytochemistry (B) and negative control (isotype-matched control) is demonstrated (C). HepG2, HuH7, Hep3B cells all express TLR9 on the lever of mRNA and protein (data not shown). Original magnification $\mathrm{x} 200$.

are capable of a proliferative response to CpG DNA, but not to non-CpG DNA. Thus, we infer that $\mathrm{CpG}$ components of DNA of hepatitis virus can directly influence liver cells proliferation.

$C p G D N A$ activates $N F-\kappa B$. NF- $\kappa \mathrm{B}$ activation was confirmed via immunofluorescence staining to NF- $\kappa B$ p65 subunit in cell nucleus. Concentrations of $1 \mu \mathrm{M}$ of CpG DNA were used for $4 \mathrm{~h}$ because they demonstrated a robust proliferative response in the MTT reduction assays. Fig. 3A1 demonstrates that $\mathrm{CpG}$ can activate NF- $\mathrm{BB}$, and the control, non-CpG DNA $(1 \mu \mathrm{M})$, can not activate NF-кB (Fig. 3A3).

HBV DNA, MP DNA, cell supernatants and extraction of cell supernatants activate $N F-\kappa B$. In order to study whether HBV DNA can activate NF-кB directly, Pblue sk-/HBV DNA containing HBV DNA full-length sequence was employed as the template to amplify HBV DNA. MP DNA and SP DNA as the control of MP DNA were amplified. HBV DNA primers were as follows: upstream primer 5'-TTT TTCACCTCTGCCTAATCA-3', downstream primer 5'-AAA AAGTTGCATGGTGCTGG-3'. MP DNA primers were as follows: upstream primer 5'-ATGGGAGGTGGTCTTCC-3', downstream primer 5'-TCAAATGTATACCCAAAGAC-3'. SP DNA primers were as follows: upstream primer 5'-ATG GAGAGCACAACA-3', downstream primer 5'-TCAAAT GTATACCCAAAGAC-3'. After 3 min of prodegeneration, for HBV DNA, PCR was performed at $94^{\circ} \mathrm{C}$ for $40 \mathrm{sec}$, $65^{\circ} \mathrm{C}$ for $5 \mathrm{~min}$ and $72^{\circ} \mathrm{C}$ for $10 \mathrm{~min}$ for 30 cycles; for MP DNA and SP DNA, PCR was performed at $94^{\circ} \mathrm{C}$ for $30 \mathrm{sec}$, $50^{\circ} \mathrm{C}$ for $30 \mathrm{sec}$ and $72^{\circ} \mathrm{C}$ for $50 \mathrm{sec}$ for 30 cycles. PCR products were separated on a $1 \%$ agarose gel and were extracted by a Gel Extract Kit. These products and the supernatant of HepG2.2.15 or HepG2 cells and extraction of nucleic acids from HepG2.2.15 supernatant and HepG2 supernatant were used to stimulate human normal liver L-02 cells. An interesting result was found that HepG2.2.15 supernatant and HBV DNA and MP DNA and extraction of nucleic acids from HepG2.2.15 can make NF-кB nuclear translocation and activate NF- $\mathrm{KB}$, but the control (HepG2 supernatant and equal volume ster deionized water and SP DNA and extraction of nucleic acids from HepG2 supernatant respectively) nearly cannot (Fig. 3B1-E4). This
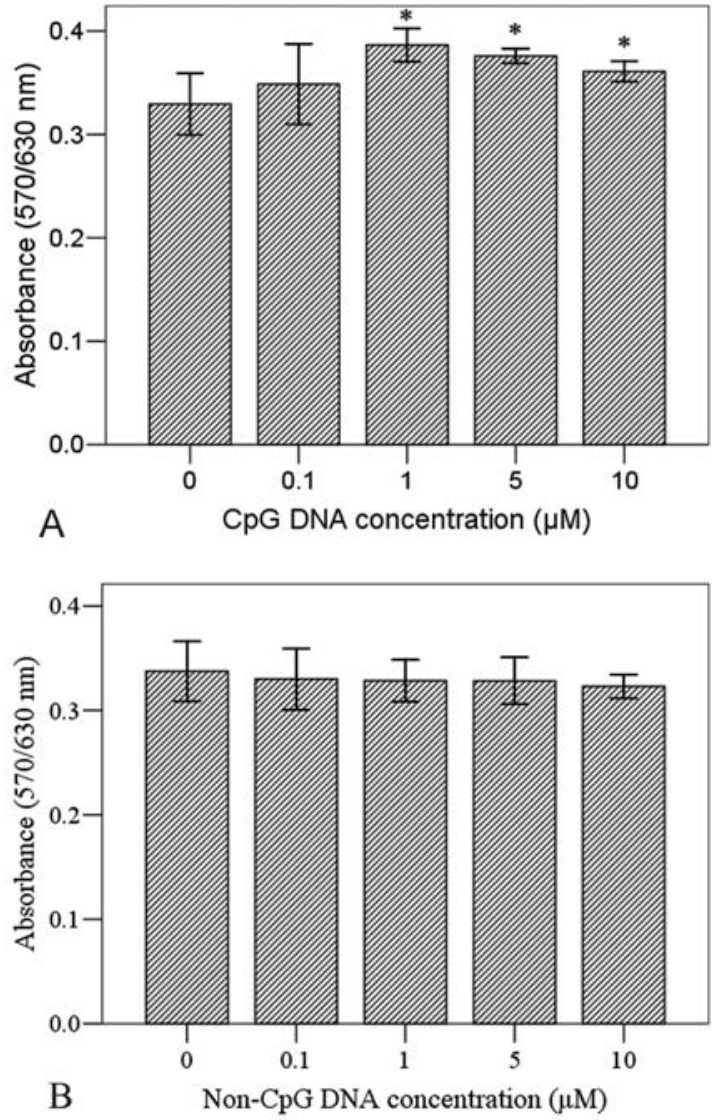

Figure 2. The proliferation effect of L-02 cells induced by CpG DNA. MTT reduction assay demonstrates L-02 cells increased dose-dependently and then declined to CpG DNA (A) and are not affected in proliferation in response to non-CpG DNA (B) $\left({ }^{*} \mathrm{p}<0.05\right)$.

is shown quantitatively in Fig. 3F where there is a significant increase in the number of NF- $\mathrm{kB}$ activated cells in each field $(p<0.01)$. However the control groups were hardly activated.

CpG DNA inhibits TNF-a induced apoptosis. Toll-like receptor stimulation is known to up-regulate various antiapoptotic genes; therefore, we tested the ability of CpG DNA to prevent apoptosis inducted by TNF- $\alpha$ of human normal liver L-02 cells by measuring Annexin V-FITC and PI 
A1

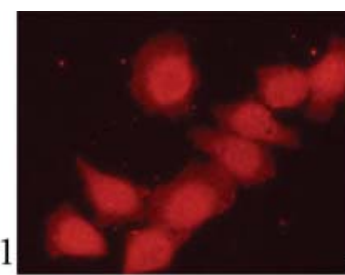

A2

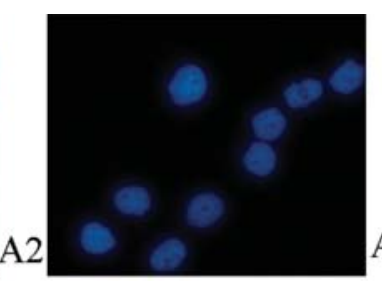

B
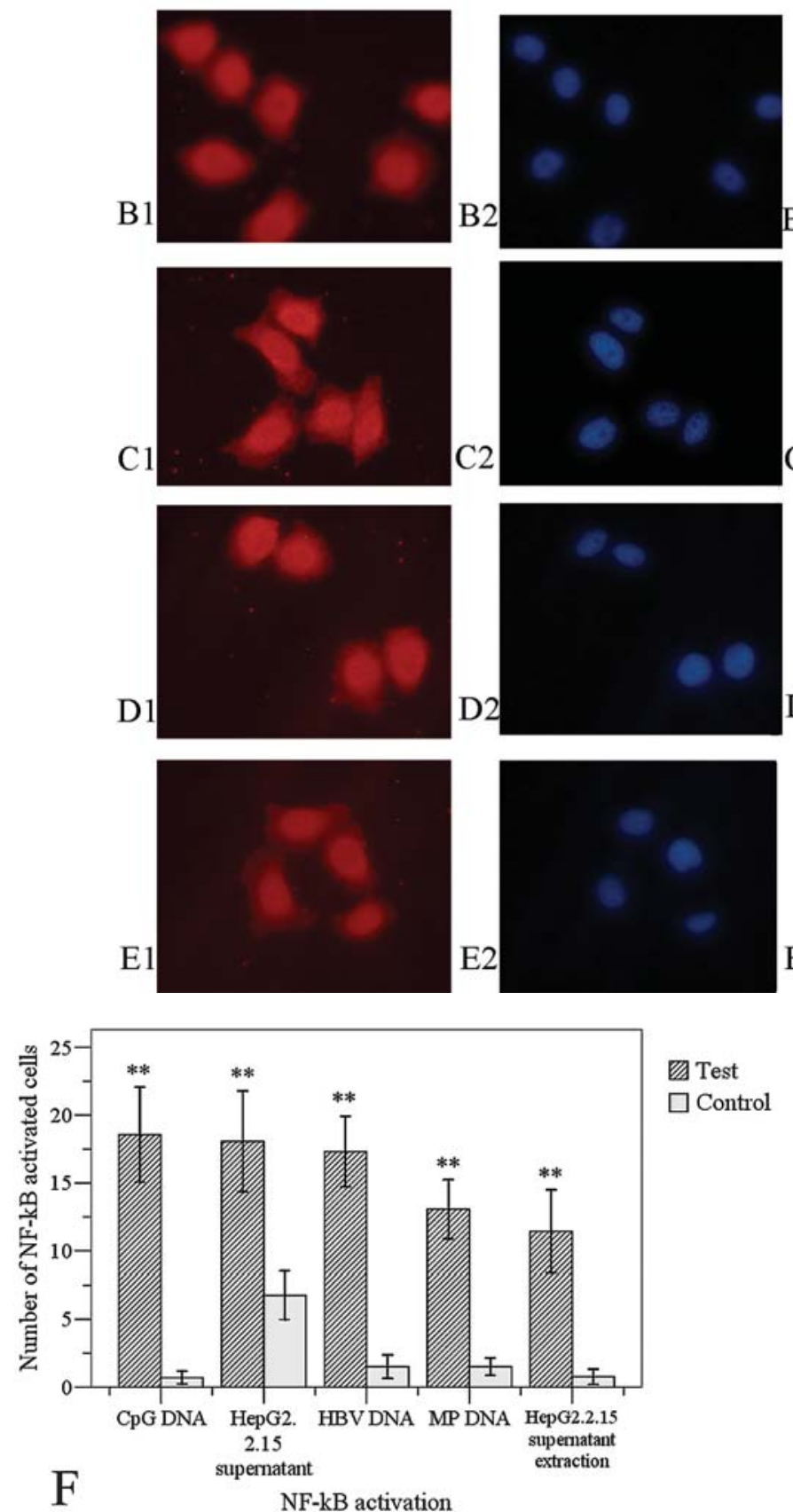

Test $\square$ Control

staining. Fig. 4A-C shows apoptosis in non-stimulated and CpG DNA-stimulated and non-CpG DNA-stimulated human normal liver L-02 cells at $<10 \%$. Apoptotic cells are about $30 \%$ using TNF- $\alpha$ (100 ng/ml) for $24 \mathrm{~h}$ (Fig. 4D). Fewer cells underwent TNF- $\alpha$ induced apoptosis when treated with $\mathrm{CpG}$ DNA (Fig. 4E). Apoptotic cells are about $20 \%$ with non-CpG DNA treatment (Fig. 4F). Values are the means \pm SD of three independent experiments.
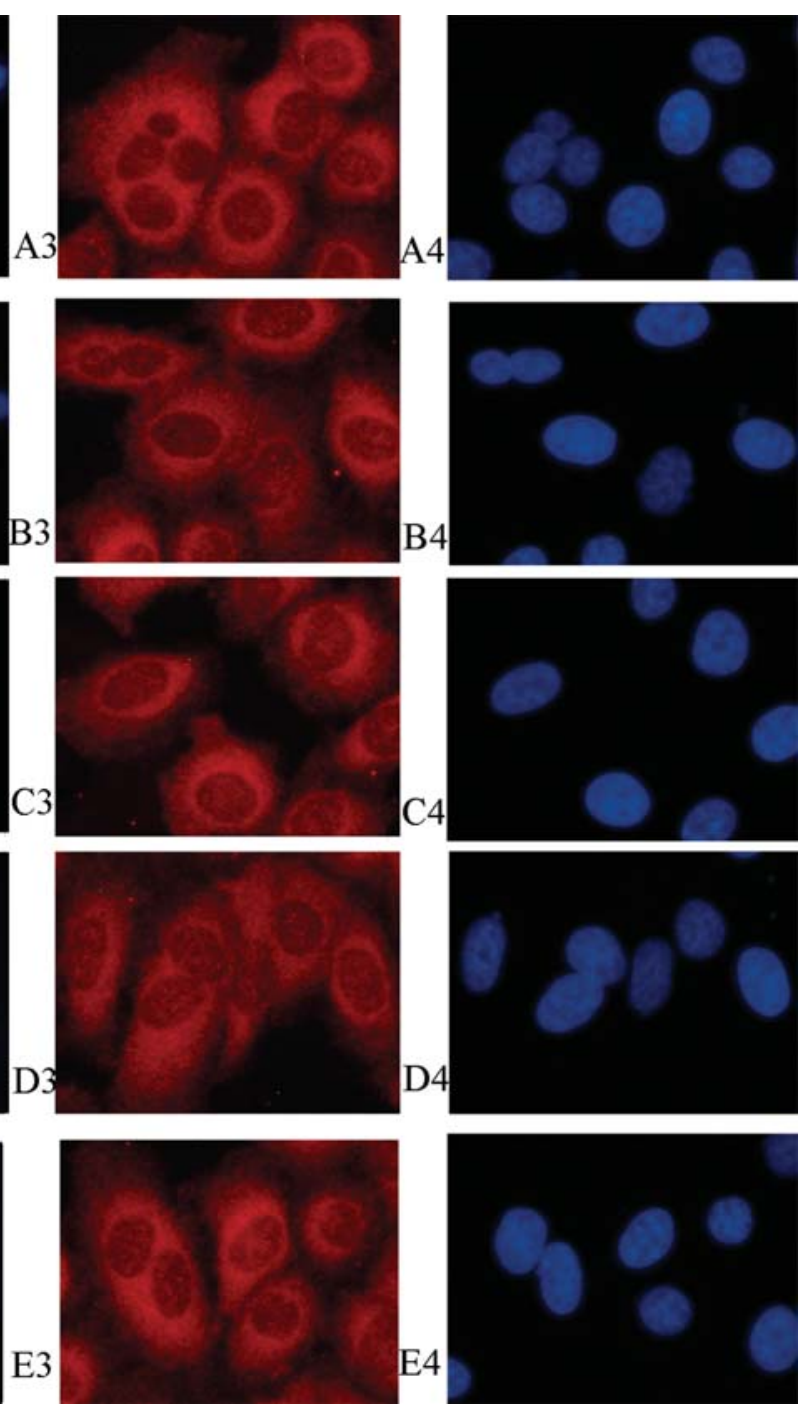

Figure 3. Different agents induce NF-кB nuclear translocation in L-02 cells. Indirect immunofluorescence analyses for cellular NF- $\mathrm{KB}$ localization were performed using chamber slide cultured L-02 cells. Nucleus location was marked by DAPI staining. Activated-NF- $\mathrm{KB}$ is localized in the nucleus and unactivated-NF- $\kappa \mathrm{B}$ is localized in the cytoplasm. p65 subunit of NF- $\mathrm{BB}$ was stained by $\mathrm{Cy} 3$ representing NF- $\kappa \mathrm{B}$. NF- $\kappa \mathrm{B}$ was activated by $1 \mu \mathrm{M}$ CpG DNA (A1 and A2), supernatant of HepG2.2.15 cells (B1 and B2), $4 \mu \mathrm{g} / \mathrm{ml} \mathrm{HBV}$ DNA (C1 and C2), $2 \mu \mathrm{g} / \mathrm{ml}$ MP DNA (D1 and D2) and extraction of Nucleic acids from HepG2.2.15 supernatant (E1 and E2). However NF-кB was not activated in the control group (respectively, in turn, non-CpG DNA (A3 and A4), HepG2 supernatant (B3 and B4), equal volume ster deionized water (C3 and C4), SP DNA (D3 and D4) and extraction of nucleic acids from HepG2 supernatant (E3 and E4). Corresponding to the above A-E groups, the number of NF-кB-activated cells in test groups are significantly increased compared with control groups $\left({ }^{* *} \mathrm{p}<0.01\right)$. The qualified analyses on the number of $\mathrm{NF}-\kappa \mathrm{B}$ activated cells in 16 fields amplified x200 (F).

CpG DNA increased mRNA expression of DNMT-1 and $B c l-2$. Regional DNA hypermethylation and increased DNMT-1 protein expression participate in the precancerous stage, in malignant progression, and have a prognostic impact on patients with cancers (5). The proto-oncogene, Bcl-2, encodes a protein that inhibits programmed cell death (apoptosis) and play a role in cell and tissue differentiation (6). Therefore, we studied the mechanism of CpG DNA induced-carcinogenesis from these two aspects by real-time 

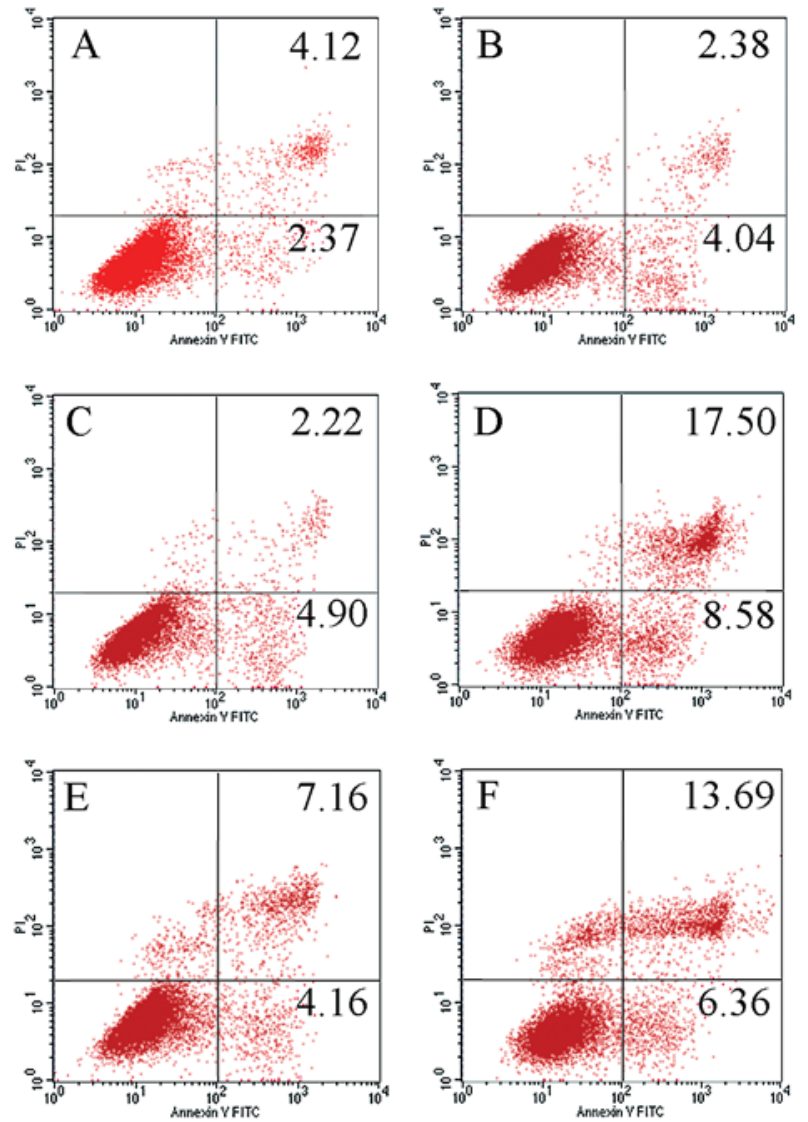

Figure 4. CpG DNA pretreatment induces resistance of L-02 cells to the apoptosis induction by TNF- $\alpha$. L-02 cells $\left(5 \times 10^{5} / \mathrm{ml}\right)$ were pretreated without (A) or with $1 \mu \mathrm{M} \mathrm{CpG} \mathrm{DNA} \mathrm{(B)} \mathrm{or} 1 \mu \mathrm{M}$ (A) non-CpG DNA (C) for $24 \mathrm{~h}$. L-02 cells $\left(5 \times 10^{5} / \mathrm{ml}\right)$ were treated with TNF- $\alpha(100 \mathrm{ng} / \mathrm{ml})$ for $24 \mathrm{~h}$ (D). L-02 cells $\left(5 \times 10^{5} / \mathrm{ml}\right)$ were pretreated with $1 \mu \mathrm{M} \mathrm{CpG} \mathrm{DNA} \mathrm{or}$ $1 \mu \mathrm{M}$ non-CpG DNA for $4 \mathrm{~h}$, then stimulated with $100 \mathrm{ng} / \mathrm{ml} \mathrm{TNF}-\alpha$ for $24 \mathrm{~h}(\mathrm{E}$ and F). The cells were stained with Annexin V-FITC and PI and subjected to FACS assay of cellular apoptosis. Values are the means \pm SD of three independent experiments. Fewer cells underwent TNF- $\alpha$ induced apoptosis when treated with CpG DNA.

RT-PCR. We found after L-02 cells were stimulated with $1 \mu \mathrm{M}$ CpG DNA for $4 \mathrm{~h}$, comparing with control group, DNMT-1 increased significantly 1.87-fold (1.63 \pm 0.27$)$ (mean

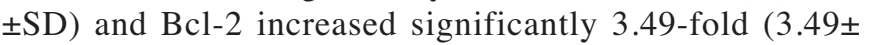
0.72). Thus, CpG DNA induced DNMT-1 and Bcl-2 production which possibly promoted carcinogenesis (Fig. 5).

\section{Discussion}

Inflammation and infection have been shown to be important in the pathogenesis of liver, colon, esophagus, stomach, cervical, and nasopharyngeal cancer by causing cell damage and creating a microenvironment rich in cytokines that can enhance cell replication, angiogenesis and tissue repair (7). It is well known that HBV leads to HCC. HCC incidence clearly correlates with $\mathrm{HBV}$ infection as $80 \%$ of HCC occur in $\mathrm{HBV}$-infected patients (8). Some studies on $\mathrm{HBV}$-induced HCC focus on the integration of HBV DNA (9-11), HBx $(12,13)$, the PreS2 activators (14), and the immune systemmediated chronic inflammation of the liver (15-17). However, no study was found on HBV DNA as an inflam-

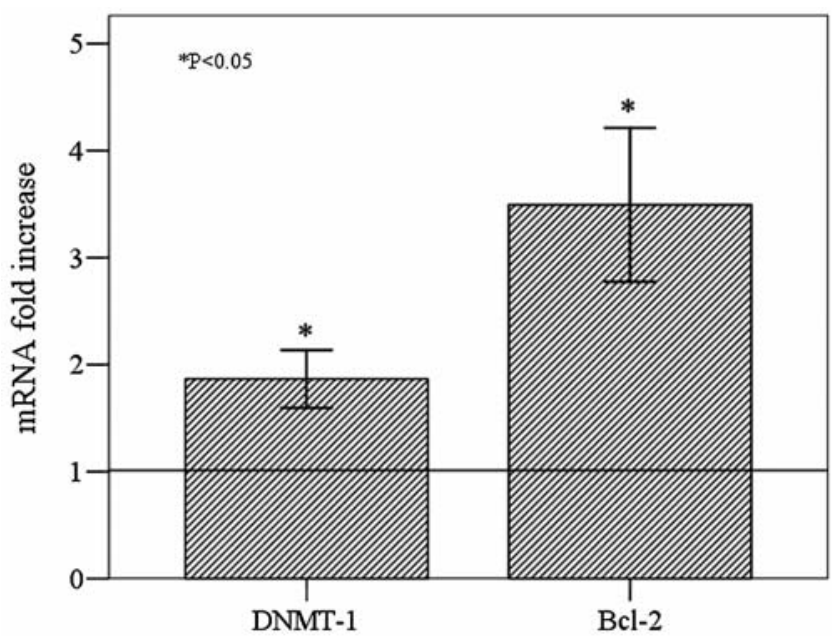

Figure 5. Effects of CpG DNA $(1 \mu \mathrm{M})$ on mRNA expression of DNMT-1 and Bcl-2. Each experiment was conducted 3 times. Data are expressed as mean \pm SD. DNMT-1 and Bcl-2 mRNA increased 1.87-fold $(1.63 \pm 0.27)$ (mean \pm SD) and 3.49-fold (3.492 \pm 0.72$)$ respectively. Compared with control, there was a significant increase $\left({ }^{*} \mathrm{p}<0.05\right)$.

mation element directly triggering cell cancerization in extrahepatocytes. CpG DNA which is a major ligand of TLR9, but not the only one (18), exists in the double strands of virus and bacteria. We discovered that TLR9 is expressed on human normal liver L-02 cells and hepatoma cell lines (HepG2, HuH7 and Hep3B), and exists in human hepatocytes (19). The proliferation of L-02 cells was found with the stimulus of the different concentration of CpG DNA as the effect on the other tumor cell lines (20). This result suggests that the liver cells are capable of responding to components of pathogens by initiating cellular proliferation.

$\mathrm{NF}-\kappa \mathrm{B}$ is correlated with the HCC significantly which is bridging the action of growth factors and inflammation to hepatic oncogenesis (21). Recent findings from several laboratories have implicated constitutive activation of NF-кB as one of the early key events involved in neoplastic progression of the liver in the Mdr2-knockout mouse model. Blocking of NF- $\mathrm{KB}$ activity via hepatic expression of a Tetinducible super-repressor form of IкB-a can block tumor growth $(22,23)$. In addition, a recently published study demonstrated that NF- $\mathrm{BB}$ inhibited c-Myc induced activation of caspase- 9 and -3 through upregulation of the anti-apoptotic target genes Bcl-XL and XIAP (24). We hypothesize that components of infectious agents may further contribute to carcinogenesis through a previously unreported method and shift the balance towards uncontrolled growth. CpG DNA activates the NF- $\mathrm{NB}$ and triggers a serial of downstream effect via TLR9 (25). The CpG DNA island is rich of single copy nonmethylation locus in the genome. We found thate the sequence of HBV DNA is rich of $\mathrm{CpG}$, and concentrated on sequence of pre s2 site encoding MP of HBV but not $\mathrm{S}$ site encoding SP, by online (address: http://www.biosoft/sms/) software. We employ these agents to stimulate the L-02 cells. NF-кB was remarkably activated. We infer that HBV DNA can induce directly human normal liver L-02 cell cancerization or malignant change. 
Studies have shown that NF-кB may be a tumor initiator by expressing anti-apoptotic genes that promote cell survival such as c-FLIP, Bcl-2, and p53 (26). As Bcl-2 appears to be involved in the turnover of stem or precursor cells, it is thought to be operational in the carcinogenesis pathways (2729). We found increased mRNA expression of Bcl-2 with the stimulation of CpG DNA. At the same time, we showed that treatment of benign cells with CpG DNA could protect cells from TNF- $\alpha$ induced apoptosis, possibly altering the delicate balance between cell growth and death that leads to malignant transformation.

Recently, a study illuminated that HBV DNA is methylated in liver tissues and is non-methylated in serum from patients with high viral load. HepG2 and HepG3B cell lines can make HBV DNA methylated (30). Some studies performed almost a decade ago showed that HBV DNA can be methylated when it becomes integrated into the human genome (31). In human $\mathrm{HCC}$ with integrated $\mathrm{HBV}$ genomes, viral protein expression was found only in those cases without methylation of the HBV genome (31). DNA methylation is associated with human cancer $(29,32-34)$. The incidence of increased DNMT-1 protein expression in HCC is significantly correlated with the lever of methylation, poorer tumor differentiation and portal vein involvement. Moreover, the recurrence-free and overall survival rates of patients with HCC showing increased DNMT-1 protein expression are significantly shorter than those of patients with HCC with low level of expression (35). Hence with the interaction between HBV DNA and human liver cells, we deduce that liver cells can methylate HBV DNA via increased DNMT-1 which induces liver cell carcinogenesis. Whether the increased DNMT-1 has relation with NF- $\mathrm{KB}$ activation or not requires more work.

Some limitations of this study warrant discussion. We have used immortalized human normal liver L-02 cells for the studies. These cells allow us to study in vitro behavior. However, cells may behave differently in vivo. In future we will utilize in vivo models to further analyze the effects of HBV DNA activated L-02 on oncogenesis in athymic mice.

This study suggests that components of viral infectious agents can affect cell growth and may play a role in malignant transformation. HBV DNA may shift the balance towards altered homeostasis in a cell that has already deviated from normal gene expression. Further studies are needed to address this issue.

\section{Acknowledgements}

We thank Dr Yan Ma and Dr Hongmei Xiang for writing assistance and for material support, respectively.

\section{References}

1. Pisani P, Bray F and Parkin DM: Estimates of the world-wide prevalence of cancer for 25 sites in the adult population. Int J Cancer 97: 72-81, 2002.

2. Lupberger J and Hildt E: Hepatitis B virus-induced oncogenesis. World J Gastroenterol 13: 74-81, 2007.

3. Akira S, Uematsu S and Takeuchi O: Pathogen recognition and innate immunity. Cell 124: 783-801, 2006.

4. Medzhitov R JCJ: Innate immunity. N Engl J Med 343: 338-344, 2000 .
5. Kanai Y and Hirohashi S: Alterations of DNA methylation associated with abnormalities of DNA methyltransferases in human cancers during transition from a precancerous to a malignant state. Carcinogenesis 28: 2434-2442, 2007.

6. Ali MA, Koura BA, el-Mashad N and Zaghloul MH: The Bcl-2 and TGF-beta1 levels in patients with chronic hepatitis $\mathrm{C}$, liver cirrhosis and hepatocellular carcinoma. Egypt J Immunol 11: 83-90, 2004.

7. Palapattu GS, Sutcliffe S, Bastian PJ, Platz EA, De Marzo AM, Isaacs WB and Nelson WG: Prostate carcinogenesis and inflammation: emerging insights. Carcinogenesis 26: 1170-1181, 2005.

8. Reeves ME and DeMatteo RP: Genes and viruses in hepatobiliary neoplasia. Semin Surg Oncol 19: 84-93, 2000.

9. Paterlini-Brechot P, Saigo K, Murakami Y, Chami M, Gozuacik D, Mugnier C, Lagorce D and Brechot C: Hepatitis B virus-related insertional mutagenesis occurs frequently in human liver cancers and recurrently targets human telomerase gene. Oncogene 22: 3911-3916, 2003.

10. Horikawa I and Barrett JC: cis-Activation of the human telomerase gene (hTERT) by the hepatitis B virus genome. J Natl Cancer Inst 93: 1171-1173, 2001.

11. Hytiroglou P and Theise ND: Telomerase activation in human hepatocarcinogenesis. Am J Gastroenterol 101: 839-841, 2006.

12. Zhang $X$, Zhang $H$ and Ye L: Effects of hepatitis B virus $X$ protein on the development of liver cancer. J Lab Clin Med 147: 58-66, 2006.

13. Waris G and Siddiqui A: Regulatory mechanisms of viral hepatitis B and C. J Biosci 28: 311-321, 2003.

14. Hildt E, Munz B, Saher G, Reifenberg K and Hofschneider PH: The PreS2 activator MHBs(t) of hepatitis B virus activates c-raf-1/ Erk2 signaling in transgenic mice. EMBO J 21: 525$535,2002$.

15. Chisari FV, Pinkert CA, Milich DR, Filippi P, McLachlan A, Palmiter RD and Brinster RL: A transgenic mouse model of the chronic hepatitis B surface antigen carrier state. Science 230: 1157-1160, 1985

16. Ferrari C, Missale G, Boni $C$ and Urbani S: Immunopathogenesis of hepatitis B. J Hepatol 39 (Suppl 1): S36-S42, 2003.

17. Visvanathan $K$ and Lewin SR: Immunopathogenesis: role of innate and adaptive immune responses. Semin Liver Dis 26: 104-115, 2006.

18. Gursel M, Verthelyi D, Gursel I, Ishii KJ and Klinman DM: Differential and competitive activation of human immune cells by distinct classes of $\mathrm{CpG}$ oligodeoxynucleotide. J Leukoc Biol 71: 813-820, 2002.

19. Nishimura M and Naito $S$ : Tissue-specific mRNA expression profiles of human toll-like receptors and related genes. Biol Pharm Bull 28: 886-892, 2005.

20. Kundu SD, Lee C, Billips BK, Habermacher GM, Zhang Q, Liu V, Wong LY, Klumpp DJ and Thumbikat P: The toll-like receptor pathway: a novel mechanism of infection-induced carcinogenesis of prostate epithelial cells. Prostate 68: 223-229, 2008.

21. Arsura M and Cavin LG: Nuclear factor-kappaB and liver carcinogenesis. Cancer Lett 229: 157-169, 2005.

22. Greten FR, Eckmann L, Greten TF, Park JM, Li ZW, Egan LJ, Kagnoff MF and Karin M: IKKbeta links inflammation and tumorigenesis in a mouse model of colitisassociated cancer. Cell 118: 285-296, 2004.

23. Pikarsky E, Porat RM, Stein I, Abramovitch R, Amit S, Kasem S, Gutkovich-Pyest E, Urieli-Shoval S, Galun E and Ben-Neriah Y: NF-kappaB functions as a tumour promoter in inflammation-associated cancer. Nature 431: 461-466, 2004.

24. Cavin LG, Wang F, Factor VM, Kaur S, Venkatraman M, Thorgeirsson SS and Arsura M: Transforming growth factoralpha inhibits the intrinsic pathway of c-Myc-induced apoptosis through activation of nuclear factor-kappaB in murine hepatocellular carcinomas. Mol Cancer Res 3: 403-412, 2005.

25. Martin-Orozco E, Kobayashi H, Van Uden J, Nguyen MD, Kornbluth RS and Raz E: Enhancement of antigen-presenting cell surface molecules involved in cognate interactions by immunostimulatory DNA sequences. Int Immunol 11: 1111-1118, 1999.

26. Li Q, Withoff S and Verma IM: Inflammation-associated cancer: NF-kappaB is the lynchpin. Trends Immunol 26: 318-325, 2005.

27. Fiorentino M, D'Errico A, Altimari A, Barozzi C and Grigioni WF: High levels of BCL-2 messenger RNA detected by in situ hybridization in human hepatocellular and cholangiocellular carcinomas. Diagn Mol Pathol 8: 189-194, 1999. 
28. Ravazoula P, Tsamandas AC, Kardamakis D, Gogos C, Karatza C, Thomopoulos K, Tepetes K, Kourelis T, Petsas T, Bonikos DS and Karavias D: The potential role of bcl-2 mRNA and protein exression in hepatocellular carcinomas. Anticancer Res 22: 1799-1805, 2002.

29. Osman HG, Gabr OM, Lotfy S and Gabr S: Serum levels of bcl-2 and cellular oxidative stress in patients with viral hepatitis. Indian J Med Microbiol 25: 323-329, 2007.

30. Vivekanandan P, Thomas D and Torbenson M: Hepatitis B viral DNA is methylated in liver tissues. J Viral Hepat 15: 103-107, 2008 .

31. Chen JY, Hsu HC, Lee CS, Chen DS, Zuckerman AJ and Harrison TJ: Detection of hepatitis B virus DNA in hepatocellular carcinoma: methylation of integrated viral DNA. J Virol Methods 19: 257-263, 1988.

32. Peng DF, Kanai Y, Sawada M, Ushijima S, Hiraoka N, Kosuge T and Hirohashi S: Increased DNA methyltransferase 1 (DNMT1) protein expression in precancerous conditions and ductal carcinomas of the pancreas. Cancer Sci 96: 403-408, 2005 .
33. Sawada M, Kanai Y, Arai E, Ushijima S, Ojima H and Hirohashi S: Increased expression of DNA methyltransferase 1 (DNMT1) protein in uterine cervix squamous cell carcinoma and its precursor lesion. Cancer Lett 251: 211-219, 2007.

34. Etoh T, Kanai Y, Ushijima S, Nakagawa T, Nakanishi Y, Sasako M, Kitano S and Hirohashi S: Increased DNA methyltransferase 1 (DNMT1) protein expression correlates significantly with poorer tumor differentiation and frequent DNA hypermethylation of multiple $\mathrm{CpG}$ islands in gastric cancers. Am J Pathol 164: 689-699, 2004.

35. Saito Y, Kanai Y, Nakagawa T, Sakamoto M, Saito H, Ishii H and Hirohashi S: Increased protein expression of DNA methyltransferase (DNMT) 1 is significantly correlated with the malignant potential and poor prognosis of human hepatocellular carcinomas. Int J Cancer 105: 527-532, 2003. 